\title{
Female labourforce participation and modification in GDI and GEM
}

\author{
Dr Sayantani Roy Choudhury \\ Department of Management, United World School of Business, India
}

\begin{abstract}
Key word- development, female labourforce, gender related development indices, push factors, economic factors, poverty, modification, binary logistic regression.
\end{abstract}

\section{Introduction}

United Nations Development Programme's (UNDP) Annual Human Development Reports (HDRs) have successfully shifted the development debates and attention from uni-dimensional, income or Gross Domestic Product based indices to inclusion of non-income and multi-dimensional variables in measurement of development. The Human Development Index (HDI) introduced by UNDP in 1990 is a simple average of three dimension indices that measure average achievements in a country with regard to 'A long and healthy life', as measured by life expectancy at birth; 'Knowledge', as measured by the adult literacy rate and the combined primary, secondary and tertiary gross enrolment ratio; and 'A decent standard of living', as measured by estimated earned income in Purchasing Power Parity (PPP) US\$. In 1995, the UNDP introduced two new indices: a Gender-related Development Index (GDI) and a Gender Empowerment Measure (GEM). The Genderrelated Development Index adjusts the average achievements in the same three dimensions that are captured in the HDI, to account for the inequalities between men and women. The Gender Empowerment Measure focuses on opportunities and captures gender inequality in three key areas: 'Political participation and decision making power', as measured by women's and men's percentage shares of parliamentary seats; 'Economic participation and decision-making power', as measured by two indicators - women's and men's percentage in employment as legislators, senior officials and managers and women's and men's percentage shares of professional and technical positions; and 'Power over economic resources', as measured by women's and men's estimated earned income (PPP US\$). If we rely on these gender related indicators to find out the situation of women of a country, there would be a problem. To calculate these indices we have to use women labourforce participation rate which depends on some implicit variables. For those variables, data cannot reveal the truth.

We can say it in other words. The GDI and GEM can be higher in a particular country due to high female labourforce participation rate of that country. This high value of GDI and GEM may reveal betterment of women there. But if women join the labourforce due to distress, due to poverty; how would it be concluded in betterment of women's situation. Therefore there is a paradox situated here. To solve the paradox, to use the data on female labourforce participation properly, the reasons behind female labourforce participation decision must be understood.

Therefore, the basic research question of this paper is about the relationship between female labourforce participation decision and economic development.

\section{Literature emphasizing alteration in gender related development indicators-}

Every decision taken by female ultimately goes into their well-being and their well-being reflects into the different gender related development indicators. Therefore, the research may end with the findings of some other, new indicators or with some alterations in the existing gender related indicators. Studies found a positive relationship between gender equality and economic growth: the higher the gender equality, the higher the growth rate (Dollar and Gatti, 1999; Klasen, 1999). In these studies, gender equality is defined as equality in education. Seguino (2000) finds that high growth is accompanied by low gender equality. She uses relative female to male wages to measure gender equality and focuses on East Asian economies between 1975 and 1995. High female-male wage differentials and high growth were also accompanied by high exports. It seems that results are not only contingent upon different scenarios, but also depend on what variable is used to measure gender inequality. In order to reach more definite conclusions on the relationship between gender equality and economic growth, an indicator is needed that combines several dimensions of equality. UNDP's pioneering work in developing GDI and GEM has been important in raising attention for gender inequality in international policy debates, as well as in raising attention among academics for the issue of measuring gender inequality. The GDI is meant to be a measure of relative well being. In analogy with the Human Development Index (HDI) 
it uses the variables adjusted income, education and health. The GEM is meant to be a measure of relative female economic and political power. It includes the share of women in parliament, the share of women in technical and professional, and management and administrative positions, and (unadjusted) income. Both measures have since been computed annually. One of the weaknesses of both GDI and GEM is that they do not measure gender equality as such, but instead some combination of absolute levels of achievement and a punishment for inequality (Dijkstra and Hanmer, 2000; Bardhan and Klasen, 1999). This implies that they cannot be used for assessing the relationship between gender equality and economic performance. Other criticisms are directed to the choice of variables and indicators, and to the construction of the overall index. So far, UNDP has hardly changed the basic principles and the methodology for computing GDI and GEM. In response to one of the issues raised by Bardhan and Klasen (1999), UNDP has changed the computation of the GDI as of the Revisiting UNDP'S GDI and GEM: Towards an alternative, 1999 Human Development Report (UNDP, 1999; UNDP, 2000). Inspired by the GDI and GEM, several alternative composite indices for gender equality have been suggested (Bardhan and Klasen, 1999; Dijkstra and Hanmer, 2000; Forsythe et al., 1998; White, 1997).

Prabhu K.S., Sarker P.C., Radha A. (1996) gave attention to the problems associated with the construction of a GDI at the sub-national level in developing countries using data for 15 Indian states. The analysis shows that a variety of rankings of gender-related income attainment and the GDI can be obtained for Indian states using various measures of workforce participation rates and wage rates. The sharp changes in ranks which may be obtained with different sets of data show that there is need for exercising caution while deriving policy measures based on these ranks. Kerala has been considered relatively free from the conventional restrictions against women's education and employment, or women owning property. Indeed, the state level gender development index estimated by several scholars places Kerala ahead of other states. But a decomposition of this index reveals that the top position in education and health masks the poor employment profile of women in the state. It has been shown in paper 'Looking beyond Gender Parity Gender Inequities of Some Dimensions of Well-Being in Kerala' of Kodoth P, Eapen M. (2005). Rustagi P. (2004) illustrated the complexities of gender-related development through an analysis of individual indicators covering issues of women's work, education, health, survival, safety and participation in public/private decision-making. State level comparisons based on selected individual gender-related indicators revealed divergent patterns of development, highlighting the problems that complexity and non-linearity pose for measuring gender development. In the absence of unilinear patterns of gender development across Indian states, the significance of non-composite indicators and their importance for problem identification and effective intervention is highlighted. Charmes J., Wieringa S. (2003), in their paper 'Measuring Women's Empowerment: an assessment of the Gender-related Development Index and the Gender Empowerment Measure' described work underway to enrich the present tools to measure women's empowerment, particularly the Gender-related Development Index (GDI) and the Gender Empowerment Measure (GEM). The authors have developed an African Gender and Development Index (AGDI) on behalf of the Economic Commission for Africa, which is to be launched in 2004. The paper began with a discussion of gender and power concepts, and then introduces a Women's Empowerment Matrix as a tool to help link socio-cultural, religious, political, legal, and economic spheres. It then raised some of the difficulties related to the calculation of the GDI and GEM, which the authors are taking into account in the AGDI.

In 2005 and 2006, the Human Development Report Office undertook a review of UNDP's genderrelated indicators, particularly the Gender-Related Development Index (GDI) and the Gender Empowerment Measure (GEM). Background papers as well as the results of the process were published in 2006 (e.g. Klasen 2006a), and summarized in the Human Development Report 2006. A paper by Klasen S. and Schüler D. (2009) extended by adjusting and extending some of the recommendations made there, by making concrete proposals for the two gender-related indicators and by presenting illustrative results for these proposed measures. The most important proposals included the calculation of a male and female HDI, as well as a gender gap index GGI to replace the GDI, that can be interpreted more directly as a measure of gender inequality. Regarding the GEM, the most important changes were different ways to deal with the earned income component and also to replace it with a more straight-forward procedure to calculate the measure. As shown below, the ranking of countries became very different for the new measures proposed there, compared to the current GDI and GEM. Another work done by Branisa B., Klasen S. and Ziegler M. (2009) in their paper 'New Measures of Gender Inequality: The Social Institutions and Gender Index (SIGI) and its Sub-indices' constructed the Social Institutions and Gender Index (SIGI) and its five sub-indices Family code, Civil liberties, Physical integrity, Son Preference and Ownership rights using variables of the OECD Gender, Institutions and Development database. Instead of measuring gender inequalities in education, health, economic or political participation, these new indices allow a new perspective on gender issues in developing countries. The SIGI and the sub-indices measure long-lasting social institutions which are mirrored by societal practices and legal norms that might produce gender inequalities. The sub-indices measure each one dimension of the concept and the SIGI combines the sub-indices 
into a multidimensional index of deprivation of women. Methodologically, the SIGI is inspired by the FosterGreer-Thorbecke poverty measures. It offers a new way of aggregating gender inequality in several dimensions, penalizing high inequality in each dimension and allowing only for partial compensation between dimensions. The SIGI and the sub-indices are useful tools to identify countries and dimensions of social institutions that deserve attention. Empirical results confirm that the SIGI provides additional information to that of other wellknown gender-related indices.

Folbre N.(2006) showed how should "care" be defined and measured in ways that enhance our understanding of the impact of economic development on women. This paper addresses this question, suggesting several possible approaches to the development of indices that would measure gender differences in responsibility for the financial and temporal care of dependents. The aim of the paper 'Revisiting UNDP's GDI and GEM: towards an alternative' by Dijkstra A.G. (2001) was twofold. First, it provided a critical review of the two gender equality measures that have been developed by UNDP in its 1995 Human Development Report (UNDP, 1995). Until now, most academic attention has been directed to the Gender related Development Index (GDI) and much less to the Gender Empowerment Measure (GEM). In identifying strengths and weaknesses of both indices, and especially on the GEM, the paper brought new insights to the fore. The second aim of the paper was to develop a new alternative measure of gender equality. This new measure, the Standardized Index of Gender Equality (SIGE) drew on the good aspects of GDI and GEM while at the same time attempting to avoid their methodological limitations. The measurement of gender inequality in societies has become an important topic in the academic literature. One reason is that gender equality is an important issue in itself. National and regional governments, as well as citizens and NGOs are concerned about eliminating gender discrimination and improving the relative situation of women. They want benchmarks and indicators to compare the achievements in furthering an equal position of women with that in other countries and to assess the progress made over time. The second reason why measuring gender equality has become important is that there is renewed attention for the relationship between gender equality and economic growth. The question is whether more gender equality promotes or hampers growth.

Dijkstra A. G. (2006) explained that both the Gender-related Development Index (GDI) and the Gender Empowerment Measure (GEM) represent a "false start" in measuring gender equality. This is because they do not measure gender (in)equality as such, but an odd combination of absolute welfare levels and gender equality that is not easy to interpret. This note argued that the United Nations Development Programme's Human Development Report Office should take the lead in either constructing a new index for measuring gender equality or elaborating a revised GDI and revised GEM that do measure gender equality. Detailed recommendations are given for both possibilities on how this can be done, partly on the basis of a brief review of alternatives presented in the literature. The paper, 'Gender-related Indicators of Well-being' by Klasen S. (2004) discusses the rationale as well as the challenges involved when constructing gender-related indicators of well-being. It argues that such indicators are critically important but that their construction involves a number of conceptual and measurement problems. Among the conceptual issues considered are the space in which gender inequality in well-being is to be measured, whether the indicators should track wellbeing of males and females separately or adjust overall measures of well-being by the gender inequality in well-being, whether gender equality in every indicator is necessarily the goal, how to assess gender inequality that is apparently desired by males and females, and what role indicators of agency or empowerment should play in gender related indicators of well-being. Among the most important measurement issues addressed are; the role of the household in allocating resources, the question of stocks versus flows, as well as significant data gaps when it comes to gender inequalities. Where appropriate, remedies to the conceptual and measurement issues are proposed. The paper also briefly reviews UNDP's gender-related indices to illustrate some of the challenges involved.

The 'feminisation of poverty' is often referred to without adequate specification or substantiation, and does not necessarily highlight aspects of poverty which are most relevant to women at the grassroots. The UNDP's gender indices go some way to reflecting gendered poverty, but there is scope for improvement. In order to work towards aggregate indices which are more sensitive to gender gaps in poverty as identified and experienced by poor women the main aims of this paper are two-fold. The first is to draw attention to existing conceptual and methodological weaknesses with the 'feminisation of poverty', and to suggest how the construct could better depict contemporary trends in gendered privation. The second is to propose directions for the kinds of data and indicators which might be incorporated within the GDI or GEM, or, used in the creation of a Gendered Poverty Index (GPI). This has been discussed in the paper 'Re-thinking the feminization of poverty in relation to aggregate gender indices' by Chant S. (2006).

Sonpar S. and Kapur R. (2001) in their paper indicated prevalence of mental distress and of abuse and violence were important indicators of the well- being of a community and were significantly differentiated by gender. The socio-economic changes wrought by structural reforms have the potential to disrupt existing notions of gender in ways that could be threatening, demoralising and oppressive for women in some contexts and empowering in others. Some of these factors, especially those that concern gender ideology, may indeed be 
difficult to 'measure'. It is therefore necessary to consider research methodologies that go beyond the quantitative in order to do justice to the complexity of these phenomena.

Therefore many works have been done to find the relationship between economic development and female labourforce participation decision. Some have got the association between female labourforce participation rate and economic development positive, some got it negative and some argued the relation is curvilinear. Thus, there is a need to examine it again.

On the other hand, literatures are there showing different kind of association among all possible economic and social factors with female labourforce participation decision. But that has not ended as we find the same set of variables plays differently to determine female labourforce participation rate in different country, different region and even in different time. So, many other factors are there to bring into consideration such as culture, historical background, attitude and many more.

And lastly, there are huge numbers of literature criticized and suggested alternative as well as modifications in existing gender related development indices, but these did not take female labourforce participation decision into consideration. According to the determinants of female labourforce participation decision, according to the actual relationship between economic development and female labourforce participation rate, some alteration may be needed in the existing gender related development indicators. The weight of female labourforce participation rate in the gender related development indices may be changed according to the importance of this in revealing the true development of the conditions of women in a particular region.

To analyse female labourforce participation decision two sets of unit level data have been used. The following variables are chosen from NFHS-3 data ${ }^{1}$ -

\begin{tabular}{|l|l|l|l|}
\hline 1 & Sector & 8 & $\begin{array}{l}\text { Number of elderly female member in } \\
\text { family }\end{array}$ \\
\hline 2 & Religion & 9 & Educational attainment \\
\hline 3 & Caste & 10 & Current marital status \\
\hline 4 & Number of household member & 11 & Husband's occupation \\
\hline 5 & Sex of household head & 12 & Structure of family \\
\hline 6 & Relation with house hold head & 13 & Wealth of family \\
\hline 7 & Number of children of age below 5 years & \multicolumn{2}{|l|}{} \\
\hline
\end{tabular}

Description of some variables-

About structure of the family (as per NFHS-3 definition)

Structure of the family can be nuclear or non-nuclear.

About wealth index (as per NFHS-3 definition)

One of the background characteristics used throughout this report is an index of the economic status of households called the wealth index. Each household is then assigned a score for each asset, and the scores were summed for each household; individuals are ranked according to the score of the household in which they reside. The sample is then divided into quintiles i.e., five groups with an equal number of individuals in each. In NFHS-3, one wealth index has been developed for the whole sample and for the country as a whole.

Household possession, which have been used to construct wealth index

i) Household goods

Mattress, Pressure cooker, Chair, Cot or bed ,Table, Electric fan, Radio or Transistor, Television (black and white), Television (colour), Any Television, sewing machine, Mobile telephone, Any other type of telephone, Computer, Refrigerator Watch or clock, Water pump, Thresher, Tractor, None of the above .

ii) Means of transport iii) Others

Bicycle, Motorcycle or scooter, Animal-drawn cart, Car, None of the above.

Percentage having a bank/post office account, Percentage covered by scheme/health insurance, Percentage owning a BPL,

\footnotetext{
1 The National Family Health Survey (NFHS) is a large-scale, multi-round survey conducted in a representative sample of households throughout India. Three rounds of the survey have been conducted since the first survey in 1992-93. The survey provides state and national information for India on fertility, infant and child mortality, the practice of family planning, maternal and child health, reproductive health, nutrition, anaemia, utilization and quality of health and family planning services. Each successive round of the NFHS has had two specific goals: a) to provide essential data on health and family welfare needed by the Ministry of Health and Family Welfare and other agencies for policy and programme purposes, and b) to provide information on important emerging health and family welfare issues.
} 
About marital status (as per NFHS-3 definition)

It can be never married, married, living together, divorced, and widowed and not living together.

About educational attainment (as per NFHS-3 definition)

It depends on educational achievements. It can be no education, incomplete primary, complete primary, incomplete secondary, complete secondary and higher than that.

About husband's occupation (as per NFHS-3 definition)

It is grouped according to the different types of occupations such as professional, sales worker, service worker, production worker, agricultural worker, other worker. It can be 'not working' also.

Data description

NFHS-3 interviewed men age 15-54 and never married women age 15-49, as well as ever-married women. NFHS-3 collected information from a nationally representative sample of 109,041 households, 124,385 women age 15-49, and 74,369 men age 15-54. The NFHS-3 sample covers 99 percent of India's population living in all 29 states. Fieldwork for NFHS-3 was conducted in two phases from November 2005 to August 2006.

\section{Proposition}

Respondent's status $=\mathrm{f}$ (sector, religion, caste, number of household member, sex of household head, relation with household head, number of children of age below 5 years, number of elderly female member in family, educational attainment, current marital status, husband's occupation, structure of family, wealth of family).

[Here, respondent's status $=1$; if she is working and respondent's status $=0$; if she is not working.]

About respondent's work-status, as per NFHS-3 definition

NFHS-3 asked women and men several questions regarding their labourforce participation through a sequence of questions. First women were asked if they had done any work in the seven days preceding the survey. In order to minimize under-reporting of women's work, women were asked an additional question to probe for informal work participation in the past seven days. Persons found to be not employed in the past seven days were asked if they were employed at any time in the 12 months preceding the survey.

\section{Methodology-}

The research tries to find out the reasons behind the female labourforce participation decision and therefore the only dependent variable is female respondent's working status. This is a closed ended question which can be either 'yes' or 'no' according to 'working' or 'not working'. Thus the dependent variable, i.e., 'respondent's status' can only have ' 0 ' for 'not working' and ' 1 ' for 'working'; the binary logistic model has been used.

\section{The results-}

Table 1.1 to 1.6

Table 1.1

\begin{tabular}{|c|c|c|c|c|c|c|c|c|}
\hline & \multicolumn{9}{|c|}{ STATES } \\
\cline { 2 - 10 } & \multicolumn{2}{|c|}{$\begin{array}{c}\text { JAMMU \& } \\
\text { KASHIR }\end{array}$} & \multicolumn{2}{c|}{$\begin{array}{c}\text { HIMACHAL } \\
\text { PRADESH }\end{array}$} & \multicolumn{2}{c|}{ PUNJAB } & \multicolumn{2}{c|}{ HARYANA } \\
\hline VARIABLES & $\begin{array}{c}\text { Odd } \\
\text { ratio }\end{array}$ & P value & $\begin{array}{c}\text { Odd } \\
\text { ratio }\end{array}$ & P value & $\begin{array}{c}\text { Odd } \\
\text { ratio }\end{array}$ & P value & $\begin{array}{c}\text { Odd } \\
\text { ratio }\end{array}$ & P value \\
\hline SECTOR & 1.578 & $.000^{*}$ & 1.001 & $.095^{*}$ & 0.679 & $.000^{*}$ & 1.256 & $.049^{*}$ \\
\hline RELIGION & 1.061 & $.038^{*}$ & 1.002 & .763 & 0.997 & .708 & 0.867 & $.027^{*}$ \\
\hline CASTE & 1.62 & $.000^{*}$ & 0.921 & .598 & 1.106 & .420 & 0.884 & .610 \\
\hline $\begin{array}{c}\text { NO OF HH } \\
\text { MEMBER }\end{array}$ & 1.074 & $.001^{*}$ & 0.995 & .860 & 0.996 & .972 & 0.987 & .611 \\
\hline $\begin{array}{c}\text { NO OF } \\
\text { CHILDREN }\end{array}$ & 0.834 & $.000^{*}$ & 0.964 & .517 & 0.775 & $.000^{*}$ & 0.821 & $.000^{*}$ \\
\hline $\begin{array}{c}\text { ELDERLY } \\
\text { WOMEN }\end{array}$ & 1.025 & .874 & 0.981 & .742 & 1.044 & .449 & 1.136 & $.050^{*}$ \\
\hline EDUCATION & 0.787 & $.067^{*}$ & 1.012 & .714 & 1.048 & .433 & 0.994 & .868 \\
\hline $\begin{array}{c}\text { RELATION TO } \\
\text { HEAD }\end{array}$ & 0.025 & $.143^{*}$ & 0.984 & .476 & 0.984 & .445 & 0.985 & .464 \\
\hline SEX OF HEAD & 0.974 & $.173^{*}$ & 0.749 & $.009^{*}$ & 1.386 & $.011^{*}$ & 1.347 & $.036^{*}$ \\
\hline WEALTH & 0.848 & $.001^{*}$ & 0.869 & $.011^{*}$ & 0.653 & $.000^{*}$ & 0.75 & $.000^{*}$ \\
\hline
\end{tabular}


Female labourforce participation and modification in GDI and GEM

\begin{tabular}{|c|c|c|c|c|c|c|c|c|}
\hline $\begin{array}{c}\text { MARITAL } \\
\text { STATUS }\end{array}$ & 1.058 & .450 & 1.431 & $.000^{*}$ & 0.962 & .601 & $1.2 *$ & $.022^{*}$ \\
\hline $\begin{array}{c}\text { HUSBAND'S } \\
\text { OCCUPATION }\end{array}$ & 0.981 & $.085^{*}$ & 0.97 & $.022^{*}$ & 1.005 & .489 & 0.956 & $.012^{*}$ \\
\hline $\begin{array}{c}\text { FAMILY } \\
\text { STRUCTURE }\end{array}$ & 0.807 & $.000^{*}$ & 1.113 & $.118^{*}$ & 0.94 & .337 & 1.08 & .341 \\
\hline
\end{tabular}

Table 1.2

\begin{tabular}{|c|c|c|c|c|c|c|}
\hline & \multicolumn{6}{|c|}{ STATES } \\
\cline { 2 - 7 } & \multicolumn{2}{|c|}{ UTTARANCHAL } & \multicolumn{2}{c|}{ RAJASTHAN } & \multicolumn{2}{c|}{ UTTAR PRADESH } \\
\hline $\begin{array}{c}\text { VARIABLE } \\
\text { S }\end{array}$ & Odd ratio & P value & Odd ratio & P value & Odd ratio & P value \\
\hline SECTOR & 2.422 & $.000^{*}$ & 2.869 & $.000^{*}$ & 0.962 & .495 \\
\hline RELIGION & 0.978 & .318 & 0.696 & $.000^{*}$ & 0.995 & .293 \\
\hline CASTE & 1.159 & .346 & 2.143 & $.000^{*}$ & 0.81 & .315 \\
\hline $\begin{array}{c}\text { NO OF HH } \\
\text { MEMBER }\end{array}$ & 0.936 & $.012^{*}$ & 1.02 & .338 & 1.002 & .830 \\
\hline $\begin{array}{c}\text { NO OF } \\
\text { CHILDREN }\end{array}$ & 0.907 & $.065^{*}$ & 0.876 & $.001^{*}$ & 0.884 & $.000^{*}$ \\
\hline $\begin{array}{c}\text { ELDERLY } \\
\text { WOMEN }\end{array}$ & 1.215 & $.001^{*}$ & 0.965 & .493 & 1.123 & $.000^{*}$ \\
\hline $\begin{array}{c}\text { EDUCATIO } \\
\text { N }\end{array}$ & 1.092 & $.004^{*}$ & 0.885 & $.000^{*}$ & 0.923 & $.000^{*}$ \\
\hline $\begin{array}{c}\text { RELATION } \\
\text { TO HEAD }\end{array}$ & 0.972 & .310 & 0.998 & .474 & 0.943 & .429 \\
\hline $\begin{array}{c}\text { SEX OF } \\
\text { HEAD }\end{array}$ & 1.358 & $.013^{*}$ & 1.291 & $.080^{*}$ & 1.432 & $.000^{*}$ \\
\hline WEALTH & 0.703 & $.000^{*}$ & 0.833 & $.000^{*}$ & 0.697 & $.000^{*}$ \\
\hline $\begin{array}{c}\text { MARITAL } \\
\text { STATUS }\end{array}$ & 1.244 & $.007^{*}$ & 1.242 & $.000^{*}$ & 1.01 & $.016^{*}$ \\
\hline $\begin{array}{c}\text { HUSBAND' } \\
\text { S } \\
\text { OCCUPATI } \\
\text { ON }\end{array}$ & 0.048 & .755 & 0.988 & .101 & 0.298 & .472 \\
\hline $\begin{array}{c}\text { FAMILY } \\
\text { STRUCTU } \\
\text { RE }\end{array}$ & 0.947 & .391 & 0.846 & $.005^{*}$ & 0.843 & $.000^{*}$ \\
\hline
\end{tabular}

Table 1.3

\begin{tabular}{|c|c|c|c|c|c|c|c|c|}
\hline & \multicolumn{8}{|c|}{ STATES } \\
\hline & \multicolumn{2}{|c|}{ BIHAR } & \multicolumn{2}{|c|}{ TRIPURA } & \multicolumn{2}{|c|}{ ASSAM } & \multicolumn{2}{|c|}{ WEST BENGAL } \\
\hline VARIABLES & $\begin{array}{l}\text { Odd } \\
\text { ratio }\end{array}$ & $\mathrm{P}$ value & $\begin{array}{l}\text { Odd } \\
\text { ratio }\end{array}$ & $P$ value & $\begin{array}{l}\text { Odd } \\
\text { ratio }\end{array}$ & $\mathrm{P}$ value & $\begin{array}{l}\text { Odd } \\
\text { ratio }\end{array}$ & $\mathrm{P}$ value \\
\hline SECTOR & 1.423 & $.000^{*}$ & 0.957 & .749 & 1.285 & $.008 *$ & 0.622 & $.000 *$ \\
\hline RELIGION & 0.99 & .939 & 1 & .929 & 1.008 & .126 & 0.773 & $.000 *$ \\
\hline CASTE & 0.228 & .190 & 1.041 & .114 & 0.916 & $.000 *$ & 1.024 & $.062 *$ \\
\hline $\begin{array}{l}\text { NO OF HH } \\
\text { MEMBER }\end{array}$ & 1.008 & .714 & 0.969 & .452 & 0.969 & .261 & 0.959 & $.021 *$ \\
\hline $\begin{array}{c}\text { NO OF } \\
\text { CHILDREN }\end{array}$ & 0.793 & $.000 *$ & 0.769 & $.002 *$ & 0.693 & $.000 *$ & 0.828 & $.000 *$ \\
\hline $\begin{array}{c}\text { ELDERLY } \\
\text { WOMEN }\end{array}$ & 0.989 & .842 & 1.072 & .385 & 1.128 & $.033^{*}$ & 1.183 & $.000^{*}$ \\
\hline E14DUCATION & 0.905 & $.009 *$ & 0.955 & .335 & 0.903 & $.001 *$ & 0.894 & $.000 *$ \\
\hline
\end{tabular}


Female labourforce participation and modification in GDI and GEM

\begin{tabular}{|c|c|c|c|c|c|c|c|c|}
\hline & & & & & & & & \\
\hline $\begin{array}{c}\text { RELATION TO } \\
\text { HEAD }\end{array}$ & 0.961 & $.058^{*}$ & 1.083 & $.001^{*}$ & 1.022 & .160 & 1.028 & $.013^{*}$ \\
\hline SEX OF HEAD & 0.982 & .852 & 1.271 & .160 & 1.321 & $.012^{*}$ & 1.673 & $.000^{*}$ \\
\hline WEALTH & 0.587 & $.000^{*}$ & 0.714 & $.000^{*}$ & 0.921 & $.045^{*}$ & 0.671 & $.000^{*}$ \\
\hline $\begin{array}{c}\text { MARITAL } \\
\text { STATUS }\end{array}$ & 1.186 & $.014^{*}$ & 1.386 & $.000^{*}$ & 1.233 & $.000^{*}$ & 1.239 & $.000^{*}$ \\
\hline $\begin{array}{c}\text { HUSBAND'S } \\
\text { OCCUPATION }\end{array}$ & 1.008 & .168 & 0.943 & .185 & 1.008 & $.079^{*}$ & 0.981 & $.027^{*}$ \\
\hline $\begin{array}{c}\text { FAMILY } \\
\text { STRUCTURE }\end{array}$ & 0.917 & .163 & 0.818 & $.011^{*}$ & 0.928 & .132 & 0.84 & $.000^{*}$ \\
\hline
\end{tabular}

Table 1.4

\begin{tabular}{|c|c|c|c|c|c|c|}
\hline & \multicolumn{7}{|c|}{ STATES } \\
\cline { 2 - 7 } & \multicolumn{2}{|c|}{ JHARKHAND } & \multicolumn{2}{c|}{ ORISSA } & \multicolumn{2}{c|}{ MADHYA PRADSH } \\
\hline VARIABLES & Odd ratio & P value & Odd ratio & P value & Odd ratio & P value \\
\hline SECTOR & 3.18 & $.000^{*}$ & 0.983 & .226 & 1.729 & $.000^{*}$ \\
\hline RELIGION & 1.005 & $.045^{*}$ & 0.999 & .792 & 0.792 & $.000^{*}$ \\
\hline CASTE & 2.2 & $.000^{*}$ & 2.698 & $.000^{*}$ & 1.343 & $.000^{*}$ \\
\hline $\begin{array}{c}\text { NO OF HH } \\
\text { MEMBER }\end{array}$ & 0.991 & .730 & 0.987 & .730 & 0.976 & 106 \\
\hline $\begin{array}{c}\text { NO OF } \\
\text { CHILDREN }\end{array}$ & 0.916 & $.076^{*}$ & 0.811 & $.000^{*}$ & 0.859 & $.000^{*}$ \\
\hline $\begin{array}{c}\text { ELDERLY } \\
\text { WOMEN }\end{array}$ & 1.145 & $.058^{*}$ & 1.067 & .489 & 0.992 & .853 \\
\hline EDUCATION & 0.969 & .382 & 0.789 & $.000^{*}$ & 0.925 & $.000^{*}$ \\
\hline $\begin{array}{c}\text { RELATION TO } \\
\text { HEAD }\end{array}$ & 0.98 & .293 & 1.012 & .489 & 1.003 & .836 \\
\hline SEX OF HEAD & 1.139 & .242 & 1.948 & $.000^{*}$ & 1.347 & $.013^{*}$ \\
\hline WEALTH & 0.662 & $.000^{*}$ & 0.658 & $.000^{*}$ & 0.712 & $.000^{*}$ \\
\hline $\begin{array}{c}\text { MARITAL } \\
\text { STATUS }\end{array}$ & 1.497 & $.000^{*}$ & 1.339 & $.000^{*}$ & 1.389 & $.000^{*}$ \\
\hline $\begin{array}{c}\text { HUSBAND'S } \\
\text { OCCUPATION }\end{array}$ & 0.989 & .343 & 0.987 & $.084^{*}$ & 0.991 & .256 \\
\hline $\begin{array}{c}\text { FAMILY } \\
\text { STRUCTURE }\end{array}$ & 0.911 & .229 & 0.906 & $.008^{*}$ & 0.856 & $.001^{*}$ \\
\hline
\end{tabular}

Table 1.5

\begin{tabular}{|c|c|c|c|c|c|c|c|c|}
\hline & \multicolumn{9}{|c|}{ STATES } \\
\hline & \multicolumn{2}{|c|}{ CHATTISGARH } & \multicolumn{2}{c|}{ GUJARAT } & \multicolumn{2}{c|}{ MAHARASHTRA } & \multicolumn{2}{c|}{$\begin{array}{c}\text { ANDHRA } \\
\text { PRADESH }\end{array}$} \\
\hline VARIABLES & $\begin{array}{c}\text { Odd } \\
\text { ratio }\end{array}$ & P value & $\begin{array}{c}\text { Odd } \\
\text { ratio }\end{array}$ & $\begin{array}{c}\text { P } \\
\text { value }\end{array}$ & $\begin{array}{c}\text { Odd } \\
\text { ratio }\end{array}$ & P value & $\begin{array}{c}\text { Odd } \\
\text { ratio }\end{array}$ & $\begin{array}{c}\text { P } \\
\text { value }\end{array}$ \\
\hline SECTOR & 2.853 & $.000^{*}$ & 1.711 & $.000^{*}$ & 2.533 & $.000^{*}$ & 1.174 & $.000^{*}$ \\
\hline RELIGION & 0.899 & .199 & 1.015 & .415 & 1.006 & .308 & 0.964 & .879 \\
\hline CASTE & 1.707 & $.000^{*}$ & 0.94 & .415 & 1.832 & .606 & 1.112 & .564 \\
\hline $\begin{array}{c}\text { NO OF HH } \\
\text { MEMBER }\end{array}$ & 1.016 & .521 & 1.065 & $.016^{*}$ & 0.994 & .690 & 1.004 & .445 \\
\hline $\begin{array}{c}\text { NO OF } \\
\text { CHILDREN }\end{array}$ & 0.886 & $.021^{*}$ & 0.668 & $.000^{*}$ & 0.728 & $.000^{*}$ & 0.721 & $.003^{*}$ \\
\hline $\begin{array}{c}\text { ELDERLY } \\
\text { WOMEN }\end{array}$ & 0.981 & .748 & 1.112 & $.056^{*}$ & 1.048 & .186 & 1.101 & .324 \\
\hline EDUCATION & 0.868 & $.000^{*}$ & 0.913 & $.001^{*}$ & 0.96 & $.036^{*}$ & 0.889 & $.002^{*}$ \\
\hline RELATION & 0.957 & $.016^{*}$ & 0.972 & .103 & 0.993 & .474 & 1.053 & .553 \\
\hline
\end{tabular}




\begin{tabular}{|c|c|c|c|c|c|c|c|c|}
\hline TO HEAD & & & & & & & & \\
\hline SEX OF HEAD & 1.208 & .231 & 1.618 & $.002^{*}$ & 1.419 & $.000^{*}$ & 1.582 & .670 \\
\hline WEALTH & 0.606 & $.000^{*}$ & 0.585 & $.000^{*}$ & 0.639 & $.000^{*}$ & 0.688 & $.000^{*}$ \\
\hline $\begin{array}{c}\text { MARITAL } \\
\text { STATUS }\end{array}$ & 1.475 & $.000^{*}$ & 1.113 & .121 & 1.45 & $.000^{*}$ & 1.375 & $.000^{*}$ \\
\hline $\begin{array}{c}\text { HUSBAND'S } \\
\text { OCCUPATION }\end{array}$ & 0.946 & $.001^{*}$ & 0.984 & $.009^{*}$ & 0.99 & $.059^{*}$ & 0.995 & $.000^{*}$ \\
\hline $\begin{array}{c}\text { FAMILY } \\
\text { STRUCTURE }\end{array}$ & 1.035 & .647 & 0.797 & $.000^{*}$ & 0.878 & $.002^{*}$ & 0.866 & $.050^{*}$ \\
\hline
\end{tabular}

Table 1.6

\begin{tabular}{|c|c|c|c|c|c|c|}
\hline & \multicolumn{7}{|c|}{ STATES } \\
\hline & \multicolumn{2}{|c|}{ KARNATAKA } & \multicolumn{2}{c|}{ KERALA } & \multicolumn{2}{c|}{ TAMIL NADU } \\
\hline VARIABLES & Odd ratio & P value & Odd ratio & P value & Odd ratio & P value \\
\hline SECTOR & 1.51 & $.000^{*}$ & 0.672 & $.001^{*}$ & 1.136 & $.047^{*}$ \\
\hline RELIGION & 0.998 & .672 & 1.003 & .814 & 0.872 & $.007^{*}$ \\
\hline CASTE & 0.977 & .679 & 0.859 & $.002^{*}$ & 0.909 & $.174^{*}$ \\
\hline $\begin{array}{c}\text { NO OF HH } \\
\text { MEMBER }\end{array}$ & 1.005 & .768 & 0.941 & $.038^{*}$ & 1.073 & .646 \\
\hline $\begin{array}{c}\text { NO OF } \\
\text { CHILDREN }\end{array}$ & 0.812 & $.000^{*}$ & 0.65 & $.000^{*}$ & 0.679 & $.000^{*}$ \\
\hline $\begin{array}{c}\text { ELDERLY } \\
\text { WOMEN }\end{array}$ & 1.033 & .426 & 0.932 & .224 & 1.043 & .380 \\
\hline EDUCATION & 0.856 & $.000^{*}$ & 1.091 & $.016^{*}$ & 0.85 & $.000^{*}$ \\
\hline $\begin{array}{c}\text { RELATION TO } \\
\text { HEAD }\end{array}$ & 1.007 & .587 & 1.073 & $.000^{*}$ & 1.039 & $.038^{*}$ \\
\hline SEX OF HEAD & 1.252 & $.011^{*}$ & 0.724 & $.001^{*}$ & 1.307 & $.002^{*}$ \\
\hline WEALTH & 0.73 & $.000^{*}$ & 0.62 & $.000^{*}$ & 0.712 & $.000^{*}$ \\
\hline $\begin{array}{c}\text { MARITAL } \\
\text { STATUS }\end{array}$ & 1.24 & $.000^{*}$ & 1.586 & $.000^{*}$ & 1.279 & $.000^{*}$ \\
\hline $\begin{array}{c}\text { HUSBAND'S } \\
\text { OCCUPATION }\end{array}$ & 0.996 & .486 & 0.947 & $.000^{*}$ & 0.986 & $.057^{*}$ \\
\hline $\begin{array}{c}\text { FAMILY } \\
\text { STRUCTURE }\end{array}$ & 0.943 & .172 & 0.863 & $.002^{*}$ & 0.86 & $.003^{*}$ \\
\hline
\end{tabular}

\section{Major findings-}

The regression results for each and every state showed a very significant association. The model is totally fit for all states of India.

The major findings of this regression are as follows:

i) In all of the 21 states of India, the relation between female labourforce participation rate and number of children below five years of age is negative.

ii) Except Kerala, Punjab and Uttaranchal; education level is inversely associated with female labourforce participation rate. In Jharkhand, Himachal Pradesh, Haryana and Tripura the relationship is insignificant.

iii) In all these states, as wealth of the family increases female labourforce participation rate falls.

iv) Except Punjab, Jammu \& Kashmir, Himachal Pradesh, Uttaranchal and Assam; stability in husband's occupation brings down female labourforce participation rate.

v) From urban to rural sector, female labourforce participation rate increases. Kerala, Orissa, Punjab, Tripura, Uttar Pradesh and West Bengal are not following this trend. Out of these states, it is positively associated in Kerala, West Bengal and Punjab. It is insignificant in Orissa, Tripura and Uttar Pradesh.

vi) Marital status influences the labourforce participation decision of women. Maried women's labourforce participation is more than unmarried women.

Similarly, more women from nuclear families join labour market than women from joint families.

vii) Caste, religion, number of family member, sex of family head and number of elderly female member in family are not showing very clear picture. In some states these relationships are positive; in some states it is negative as well as insignificant. 
To analyse female labourforce participation decision the following variables are chosen from NSSO data ${ }^{2}$ :Identified variables-

\begin{tabular}{|l|l|l|l|}
\hline 1 & Sector & 7 & General education \\
\hline 2 & Religion & 8 & Technical education \\
\hline 3 & Caste & 9 & Household type \\
\hline 4 & Number of household member & 10 & Current marital status \\
\hline 5 & Age & 11 & Land possessed \\
\hline 6 & Relation with house hold head & 12 & Monthly consumption on non-durables \\
\hline
\end{tabular}

According to the NSSO definition, these are the explanations of some independent variables.

Social group: The social group of the head of the household was considered as the social group of all the members of the household irrespective of the actual social group to which the individual members belonged. In the survey, information in respect of four social groups viz. scheduled tribe (ST), scheduled caste (SC), other backward class $(\mathrm{OBC})$ and the rest referred to as others was collected.

Land possessed by the household as on date of survey: The area of land possessed included land 'owned', 'leased in' and 'land neither owned nor leased in' (i.e. encroached) by the household but exclude land 'leased out'.

Household type: The household types were assigned on the basis of the sources of the household's income during the last 365 days preceding the date of survey.

For the rural areas, household types were as follows:-

Self-employed in agriculture, non-agriculture, agricultural labour, other labour, residual other households.

For urban areas, the household types were as follows:-

Self-employed, regular wage/salary earning, casual labour, residual other households.

Household monthly per capita consumer expenditure (MPCE): The items of consumption were classified into four groups and three different approaches viz (a) consumption approach, (b) expenditure approach and (c) firstuse approach, were followed for defining consumption of items. The different groups were (i) food (other than 'cooked meals'), pan, tobacco \& intoxicants and fuel \& light, (ii) cooked meals, miscellaneous goods and services including education, medical, rent, taxes. (iii) clothing and footwear and (iv) durable goods.

General educational level: Highest level of education successfully completed by each member of the household was decided by considering his/ her all general/ technical/ vocational educational level and was recorded in terms of 12 categories viz. (i) not literate, (ii) literate without formal schooling: (a) Education Guarantee Scheme (EGS)/Non-formal Education Courses (NFEC)/ Adult Literacy Centers (AEC), (b) Total Literacy Campaign (TLC), (c) others; (iii) literate but below primary, (iv) middle, (v) secondary, (vi) higher secondary, (vii) diploma/certificate course, (viii) graduate, and (ix) postgraduate and above.

Technical educational level:

Here NSSO has used these following categories -

No technical education, technical degree in agriculture/ engineering/ technology/ medicine, diploma or certificate (below graduate level) in: agriculture, engineering/ technology, medicine, crafts, other subjects, diploma or certificate (graduate and above level) in agriculture, engineering/ technology, medicine, crafts, other subjects.

The total number of households surveyed at the all-India level was 1,24,680 (79,306 in rural areas and 45,374 in urban areas).

\section{The proposition-}

Respondent's status $=\mathrm{f}($ sector, religion, caste, number of household member, age, relation with household head, general education, technical education, household type, current marital status, land possessed, monthly consumption on non-durables).

Here, respondent's status $=1$; if she is working and respondent's status $=0$; if she is not working (as per the definition used by NSSO).

About respondent's work-status, as per NSSO definition-

It is the activity situation in which a person was found during a reference period with regard to the person's participation in economic and non-economic activities. According to this, a person could be in one or a combination of the following three broad activity statuses during a reference period:

(i) working or being engaged in economic activity (work) as defined above,

\footnotetext{
2 The National Sample Survey Office(NSSO) in India is a unique setup to carry out surveys on socio-economic, demographic, agricultural and industrial subjects for collecting data from house holds and from enterprises located in villages and in the towns. It is a focal agency of the Govt. of India for collection of statistical data in the areas which are vital for developmental planning.
} 
(ii) being not engaged in economic activity (work) but either making tangible efforts to seek 'work' or being available for 'work' if the 'work' is available and

(iii) being not engaged in any economic activity (work) and also not available for 'work'.

Broad activity statuses mentioned in (i) and (ii) above are associated with 'being in labourforce' and the last with 'not being in the labour force'. Within the labour force, broad activity status (i) and (ii) were associated with 'employment' and 'unemployment' respectively.

The people can be divided into these categories-

[A] Working (or employed)

1. Worked (self-employed) in household enterprises as own-account worker

2. Worked (self-employed) in household enterprises as an employer

3. Worked (self-employed) in household enterprises as helper

4. Worked as regular salaried/wage employee

5 . Worked as casual wage labour in public works

6. Worked as casual wage labour in other types of works

7. Did not work owing to sickness though there was work in household enterprise

8. Did not work owing to other reasons though there was work in household enterprise

9. Did not work owing to sickness but had regular salaried/wage employment

10. Did not work owing to other reasons but had regular salaried/wage employment.

[B] Not working but seeking/available for work (or unemployed)

11. Sought work or did not seek but was available for work (for usual status approach)

12. Sought work (for current weekly status approach)

13. Did not seek but was available for work (for current weekly status approach).

[C] Neither working nor available for work (or not in labour force)

14. Attended educational institutions

15. Attended to domestic duties only

16. Attended to domestic duties and was also engaged in free collection of goods (vegetables, roots, firewood, cattle feed, etc.), sewing, tailoring, weaving, etc. for

household use.

17. Rentiers, pensioners, remittance recipients, etc.

18. Not able to work owing to disability

19. Others (including beggars, prostitutes, etc.)

20. Did not work owing to sickness (for casual workers only)

21. Children of age $0-4$ years.

Labourforce: Persons who were either 'working' (or employed) or 'seeking or available for work' (or unemployed) constituted the labourforce.

\section{Methodology-}

The research tries to find out the reasons behind the female labourforce participation decision and therefore the only dependent variable is female respondent's working status. This is a closed ended question which can be either 'yes' or 'no' according to 'working' or 'not working'. Thus the dependent variable, i.e., 'respondent's status' can only have ' 0 ' for 'not working' and ' 1 ' for 'working'; the binary logistic model has been used.

The results-

Table 2.1 to 2.6

Table- 2.1

\begin{tabular}{|c|c|c|c|c|c|c|}
\hline STATE & \multicolumn{2}{|c|}{ JAMMU \& KASHMIR } & \multicolumn{2}{c|}{ HIMACHAL PRADESH } & \multicolumn{2}{c|}{ PUNJAB } \\
\hline & Odd ratio & P value & Odd ratio & P value & Odd ratio & P value \\
\hline SECTOR & .839 & .662 & .219 & $.000^{*}$ & 1.208 & .911 \\
\hline RELIGION & 1.124 & $.001^{*}$ & 1.113 & $.001^{*}$ & .931 & $.002^{*}$ \\
\hline CASTE & .983 & .992 & 1.004 & .659 & .919 & $.000^{*}$ \\
\hline NO OF HH MEMBER & .935 & $.001^{*}$ & 1.035 & $.004^{*}$ & .913 & $.003^{*}$ \\
\hline AGE & .997 & .445 & 1.003 & .268 & 1.006 & .552 \\
\hline $\begin{array}{c}\text { GENERAL } \\
\text { EDUCATION }\end{array}$ & 1.101 & $.000^{*}$ & 1.048 & $.000^{*}$ & 1.206 & $.000^{*}$ \\
\hline
\end{tabular}


Female labourforce participation and modification in GDI and GEM

\begin{tabular}{|c|c|c|c|c|c|c|}
\hline $\begin{array}{c}\text { TECHNICAL } \\
\text { EDUCATION }\end{array}$ & 1.211 & $.002^{*}$ & 1.123 & $.000^{*}$ & 1.204 & $.000^{*}$ \\
\hline RELATION TO HEAD & .968 & .722 & .635 & .992 & .887 & $.011^{*}$ \\
\hline HOUSEHOLD TYPE & .988 & .345 & .945 & $.000^{*}$ & .94 & $.000^{*}$ \\
\hline LAND POSSESSED & 1.064 & $.000^{*}$ & 1.02 & .311 & .982 & .233 \\
\hline MARITAL STATUS & 1.44 & $.003^{*}$ & 3.36 & $.005^{*}$ & 2.26 & $.010^{*}$ \\
\hline $\begin{array}{c}\text { MONTHLY } \\
\text { CONSUMPTION }\end{array}$ & 1.125 & .523 & 1.196 & $.000^{*}$ & .945 & $.000^{*}$ \\
\hline
\end{tabular}

Table 2.2

\begin{tabular}{|c|c|c|c|c|c|c|c|c|}
\hline STATE & UTTAR & NCHAL & HARY & & RAJA & AN & $\begin{array}{l}\text { UTTAR } \\
\text { PRADESH }\end{array}$ & \\
\hline & $\begin{array}{l}\text { Odd } \\
\text { ratio }\end{array}$ & $\begin{array}{l}\mathrm{P} \\
\text { value }\end{array}$ & $\begin{array}{l}\text { Odd } \\
\text { ratio }\end{array}$ & $\begin{array}{l}\mathrm{P} \\
\text { value }\end{array}$ & $\begin{array}{l}\text { Odd } \\
\text { ratio }\end{array}$ & $\begin{array}{l}\mathrm{P} \\
\text { value }\end{array}$ & Odd ratio & $\begin{array}{l}\mathrm{P} \\
\text { value }\end{array}$ \\
\hline SECTOR & .149 & $.000 *$ & .502 & $.004 *$ & .418 & $.000 *$ & .519 & $.000 *$ \\
\hline RELIGION & .856 & $.002 *$ & 1.023 & .212 & 1.022 & .998 & 1.029 & .712 \\
\hline CASTE & 1.01 & $.000 *$ & .937 & $.004 *$ & .908 & $.001 *$ & .924 & $.000 *$ \\
\hline $\begin{array}{lcc}\text { NO } & \text { OF } & \text { HH } \\
\text { MEMBER } & \end{array}$ & 1.045 & .542 & .49 & .665 & 1.011 & $.000 *$ & 1.024 & $.002^{*}$ \\
\hline AGE & 1.01 & $.010 *$ & .997 & .982 & .993 & $.006 *$ & 1.021 & $.101 *$ \\
\hline $\begin{array}{l}\text { GENERAL } \\
\text { EDUCATION }\end{array}$ & 1.08 & $.000 *$ & 1.049 & $.000 *$ & .959 & $.001 *$ & .996 & .324 \\
\hline $\begin{array}{l}\text { TECHNICAL } \\
\text { EDUCATION }\end{array}$ & 1.207 & $.000 *$ & 1.251 & $.002^{*}$ & 1.318 & $.000 *$ & 1.226 & $.022 *$ \\
\hline $\begin{array}{ll}\text { RELATION } & \text { TO } \\
\text { HEAD } & \\
\end{array}$ & .738 & $.003 *$ & .699 & $.000^{*}$ & .7 & $.035^{*}$ & .741 & $.011^{*}$ \\
\hline $\begin{array}{l}\text { HOUSEHOLD } \\
\text { TYPE }\end{array}$ & .911 & $.000 *$ & .938 & .551 & .939 & $.000 *$ & .907 & $.000^{*}$ \\
\hline $\begin{array}{l}\text { LAND } \\
\text { POSSESSED }\end{array}$ & $.689[-]^{*}$ & $.000 *$ & 1.061 & .768 & 1.089 & $.000 *$ & .806 & $.000^{*}$ \\
\hline $\begin{array}{l}\text { MARITAL } \\
\text { STATUS }\end{array}$ & 3.48 & $.000 *$ & 3.162 & $.000^{*}$ & 3.137 & $.002 *$ & 1.885 & $.014^{*}$ \\
\hline $\begin{array}{l}\text { MONTHLY } \\
\text { CONSUMPTION }\end{array}$ & $1.096^{*}$ & $.002 *$ & 1.003 & .449 & 1.223 & .449 & .904 & $.000^{*}$ \\
\hline
\end{tabular}

Table 2.3

\begin{tabular}{|l|l|l|l|l|l|l|}
\hline & \multicolumn{3}{|l|}{ JHARKHAND } & \multicolumn{2}{l|}{ ORISSA } & \multicolumn{2}{l|}{$\begin{array}{l}\text { MADHYA } \\
\text { PRADESH }\end{array}$} \\
\hline & $\begin{array}{l}\text { Odd } \\
\text { ratio }\end{array}$ & $\begin{array}{l}\text { P } \\
\text { value }\end{array}$ & $\begin{array}{l}\text { Odd } \\
\text { ratio }\end{array}$ & $\begin{array}{l}\text { P } \\
\text { value }\end{array}$ & Odd ratio & P value \\
\hline SECTOR & .477 & $.000^{*}$ & .812 & $.000^{*}$ & .461 & $.002^{*}$ \\
\hline RELIGION & 1.145 & $.011^{*}$ & 1.089 & $.003^{*}$ & .894 & $.000^{*}$ \\
\hline CASTE & .925 & $.000^{*}$ & .876 & $.000^{*}$ & .83 & $.000^{*}$ \\
\hline NO OF HH MEMBER & 1.018 & .887 & .986 & $.015^{*}$ & 1.036 & $.000^{*}$ \\
\hline AGE & 1.005 & $.004^{*}$ & 1.012 & $.003^{*}$ & .998 & .883 \\
\hline GENERAL EDUCATION & 1.01 & $.000^{*}$ & .946 & $.000^{*}$ & .966 & $.000^{*}$ \\
\hline TECHNICAL EDUCATION & 1.259 & $.000^{*}$ & 1.524 & $.001^{*}$ & 1.475 & $.000^{*}$ \\
\hline RELATION TO HEAD & .732 & $.012^{*}$ & .803 & $.025^{*}$ & .845 & $.022^{*}$ \\
\hline HOUSEHOLD TYPE & .904 & $.000^{*}$ & .874 & $.000^{*}$ & .922 & $.000^{*}$ \\
\hline LAND POSSESSED & .685 & $.000^{*}$ & .618 & $.000^{*}$ & .687 & $.000^{*}$ \\
\hline MARITAL STATUS & 3.049 & $.001^{*}$ & 1.505 & $.011^{*}$ & 3.292 & $.011^{*}$ \\
\hline MONTHLY CONSUMPTION & 1.271 & $.002^{*}$ & 1.188 & $.000^{*}$ & 1.119 & $.021^{*}$ \\
\hline
\end{tabular}


Table 2.4

\begin{tabular}{|c|c|c|c|c|c|c|c|c|}
\hline \multirow[t]{2}{*}{ STATE } & \multicolumn{2}{|c|}{ BIHAR } & \multicolumn{2}{|c|}{ "TRIPURA } & \multicolumn{2}{|c|}{ ASSAM } & \multicolumn{2}{|c|}{$\begin{array}{c}\text { WEST } \\
\text { BENGAL }\end{array}$} \\
\hline & $\begin{array}{l}\text { Odd } \\
\text { ratio }\end{array}$ & $\begin{array}{l}\mathrm{P} \\
\text { value }\end{array}$ & $\begin{array}{l}\text { Odd } \\
\text { ratio }\end{array}$ & $\begin{array}{l}\mathrm{P} \\
\text { value }\end{array}$ & $\begin{array}{l}\text { Odd } \\
\text { ratio }\end{array}$ & $\begin{array}{l}\mathrm{P} \\
\text { value }\end{array}$ & $\begin{array}{l}\text { Odd } \\
\text { ratio }\end{array}$ & $\begin{array}{l}\mathrm{P} \\
\text { value }\end{array}$ \\
\hline SECTOR & .644 & $.000^{*}$ & 1.27 & .310 & .516 & $.000 *$ & 1.211 & .345 \\
\hline RELIGION & .992 & $.003^{*}$ & 1.089 & .212 & .874 & .660 & 1.12 & $.000 *$ \\
\hline CASTE & .858 & $.000^{*}$ & 947 & $.000^{*}$ & .939 & $.000 *$ & .936 & $.000 *$ \\
\hline NO OF HH MEMBER & .977 & $.011^{*}$ & .794 & $.002 *$ & .953 & $.000^{*}$ & 974 & $.003 *$ \\
\hline AGE & 1.005 & .713 & 945 & .775 & 1.02 & $.012 *$ & 1.002 & .710 \\
\hline $\begin{array}{l}\text { GENERAL } \\
\text { EDUCATION }\end{array}$ & .985 & $.000^{*}$ & 1.049 & $.000 *$ & 1.181 & $.000 *$ & 1.012 & .662 \\
\hline $\begin{array}{l}\text { TECHNICAL } \\
\text { EDUCATION }\end{array}$ & 1.337 & $.000^{*}$ & 1.13 & .336 & 1.293 & $.000^{*}$ & 1.3 & .411 \\
\hline RELATION TO HEAD & .701 & $.020 *$ & .833 & $.001 *$ & .869 & $.007 *$ & .873 & $.014 *$ \\
\hline HOUSEHOLD TYPE & .83 & $.000^{*}$ & .878 & $.000 *$ & .91 & $.000 *$ & 927 & $.000 *$ \\
\hline LAND POSSESSED & .962 & .551 & 1.113 & .683 & .804 & $.000^{*}$ & .719 & $.000^{*}$ \\
\hline MARITAL STATUS & 5.27 & $.000 *$ & 2.334 & $.004 *$ & 1.033 & $.001 *$ & 1.697 & $.021 *$ \\
\hline $\begin{array}{c}\text { MONTHLY } \\
\text { CONSUMPTION }\end{array}$ & 1.038 & .437 & 1.187 & .985 & 1.193 & $.012 *$ & .651 & $.000^{*}$ \\
\hline
\end{tabular}

Table 2.5

\begin{tabular}{|l|l|l|l|l|l|l|l|l|}
\hline STATE & \multicolumn{2}{l|}{ CHATTISGARH } & \multicolumn{2}{l}{ GUJARAT } & \multicolumn{2}{l|}{ MAHARASHTRA } & \multicolumn{2}{l|}{$\begin{array}{l}\text { ANDHRA } \\
\text { PRADESH }\end{array}$} \\
\hline & $\begin{array}{l}\text { Odd } \\
\text { ratio }\end{array}$ & P value & $\begin{array}{l}\text { Odd } \\
\text { ratio }\end{array}$ & $\begin{array}{l}\text { P } \\
\text { value }\end{array}$ & $\begin{array}{l}\text { Odd } \\
\text { ratio }\end{array}$ & P value & Odd ratio & P value \\
\hline SECTOR & .367 & $.000^{*}$ & .409 & $.000^{*}$ & .3 & $.003^{*}$ & .334 & $.000^{*}$ \\
\hline RELIGION & .998 & .344 & .708 & $.000^{*}$ & 1.005 & .278 & .886 & $.003^{*}$ \\
\hline CASTE & .872 & $.000^{*}$ & .9 & $.000^{*}$ & .952 & $.000^{*}$ & .916 & $.000^{*}$ \\
\hline NO OF HH MEMBER & 1.079 & $.022^{*}$ & 1.025 & $.013^{*}$ & 1.019 & $.010^{*}$ & 1.041 & .422 \\
\hline AGE & .99 & .441 & 1.004 & .331 & 1.002 & .527 & .994 & $.000^{*}$ \\
\hline $\begin{array}{l}\text { GENERAL } \\
\text { EDUCATION }\end{array}$ & .968 & $.000^{*}$ & .994 & $.000^{*}$ & 1.007 & $.000^{*}$ & .935 & $.003^{*}$ \\
\hline $\begin{array}{l}\text { TECHNICAL } \\
\text { EDUCATION }\end{array}$ & 1.18 & $.000^{*}$ & 1.169 & $.000^{*}$ & 1.206 & $.000^{*}$ & 1.294 & $.000^{*}$ \\
\hline $\begin{array}{l}\text { RELATION } \\
\text { HEAD TO }\end{array}$ & .655 & $.002^{*}$ & .728 & $.005^{*}$ & .715 & $.001^{*}$ & .663 & $.020^{*}$ \\
\hline HOUSEHOLD TYPE & .88 & $.000^{*}$ & .926 & $.000^{*}$ & .861 & $.000^{*}$ & .797 & $.000^{*}$ \\
\hline LAND POSSESSED & .746 & $.000^{*}$ & .835 & $.000^{*}$ & .812 & $.000^{*}$ & .719 & $.000^{*}$ \\
\hline MARITAL STATUS & 3.16 & $.011^{*}$ & 2.296 & $.001^{*}$ & 2.558 & $.015^{*}$ & 2.262 & $.011^{*}$ \\
\hline $\begin{array}{l}\text { MONTHLY } \\
\text { CONSUMPTION }\end{array}$ & 1.112 & $.000^{*}$ & 1.362 & $.000^{*}$ & 1.313 & $.000^{*}$ & 1.371 & $.000^{*}$ \\
\hline
\end{tabular}

Table 2.6

\begin{tabular}{|l|l|l|l|l|l|l|}
\hline STATE & \multicolumn{2}{|l|}{ KARNATAKA } & \multicolumn{2}{l|}{ KERALA } & \multicolumn{2}{l|}{ TAMIL NADU } \\
\hline & Odd ratio & P value & Odd ratio & P value & Odd ratio & P value \\
\hline SECTOR & .964 & $.000^{*}$ & .832 & $.000^{*}$ & .78 & $.000^{*}$ \\
\hline RELIGION & .907 & $.002^{*}$ & .803 & $.000^{*}$ & .942 & $.002^{*}$ \\
\hline CASTE & .986 & .465 & 1.003 & .812 & .98 & .287 \\
\hline NO OF HH MEMBER & .886 & $.013^{*}$ & .885 & $.022^{*}$ & .991 & .771 \\
\hline AGE & 1.008 & $.000^{*}$ & 1.007 & $.004^{*}$ & 1.006 & $.006^{*}$ \\
\hline GENERAL EDUCATION & 1.11 & $.000^{*}$ & 1.106 & $.000^{*}$ & 1.986 & $.000^{*}$ \\
\hline TECHNICAL EDUCATION & 1.08 & $.006^{*}$ & 1.085 & $.000^{*}$ & 1.002 & .662 \\
\hline RELATION TO HEAD & .761 & $.001^{*}$ & .827 & $.030^{*}$ & .713 & $.002^{*}$ \\
\hline HOUSEHOLD TYPE & 1.02 & $.000^{*}$ & .92 & $.001^{*}$ & .996 & .312 \\
\hline LAND POSSESSED & .854 & $.002^{*}$ & .821 & $.000^{*}$ & .826 & $.000^{*}$ \\
\hline MARITAL STATUS & 1.623 & .559 & 1.623 & $.000^{*}$ & .974 & .345 \\
\hline MONTHLY CONSUMPTION & 1.035 & .662 & 1.039 & .431 & 1.012 & .558 \\
\hline
\end{tabular}




\section{Major findings-}

i) In almost all states, land possessed has a negative relationship with female labourforce participation rate. In some states like Jammu \& Kashmir, Punjab, Himachal Pradesh, Bihar and Kerala this relationship is not significant.

ii) Female labourforce participation rate among rural women is more than that of urban women. In Jammu \& Kashmir, Punjab, Tripura and West Bengal the relationship is not significant.

iii) Half of the states, Kerala, Tripura, Jammu and Kashmir, Himachal Pradesh, Punjab, Uttaranchal and Haryana, are showing positive relationship in between general education and female labourforce participation rate; in states like Jharkhand, Gujarat, Maharashtra, Rajasthan, Orissa, Madhya Pradesh, Chhattisgarh, Andhra Pradesh, Karnataka and Tamil Nadu it is negative; whereas, in Uttar Pradesh, West Bengal, it is insignificant.

iv) Except four states like West Bengal, Tripura, Kerala and Tamil Nadu technical education brings female labourforce participation rate up. The relationship is insignificant in the above mentioned states.

v) Families with more stable income source (revealed from household type) have less female labourforce participation rate in almost all states.

vi) In almost all states, women from general caste are less engaged in labourforce.

vii) Marital status becomes an important factor behind female labourforce participation rate. Labourforce participation is more from married women.

viii) Other variables, that is, 'age', 'religion', 'household size' and 'relation to head of the family', are not showing any clear trend.

The previous discussions suggest a thorough examination of factors behind female labourforce participation decision. Now, the most popular indicators used to find the development of women are Gender Related Development Index (GDI) and Gender Empowerment Measures (GEM). Both of them have a component called adjusted per capita income. This per capita income includes \% share of women in labourforce. That means, in calculation of both the indicators, the labourforce participation of female takes an important role. Ups and downs in labourforce participation rates can change the value of these two indicators a lot. Accordingly, the ranking of countries or states may also alter.

Out of all independent variables, which have been taken, four 'negative, push factors' are identified. These are 'less education', 'less wealth of family (less land owned in case of NSSO)', 'living in rural sector' and 'financial instability within her family' (reflected from household type in NSSO and husband's occupation in NFHS-3). Due to the presence of these factors female labourforce participation rate is higher in some states. If this is so, positive connection between female labourforce participation and economic development may be misleading.

Now, both unit level data sets show all of the four 'push factors' are present in Jharkhand, Chhattisgarh, Madhya Pradesh, Gujarat, Karnataka, Maharashtra and Andhra Pradesh (Table 1 and 2). Three of them are there in Uttaranchal, Uttar Pradesh, Tamil Nadu, Bihar and Rajasthan (Table 1 and 2). Assam, Orissa and Himachal Pradesh have two of them (TABLE 1 and 2). Only one of these is present in West Bengal, Tripura and Haryana; and lastly, the states Kerala, Punjab and Jammu and Kashmir are free from those 'push factors' (TABLE 1 and 2).

Table 3 'Push factors' present in different states.

\begin{tabular}{|l|l|}
\hline Push factors & States \\
\hline 'less education' & $\begin{array}{l}\text { Jharkhand, Chhattisgarh, Madhya Pradesh, Gujarat, } \\
\text { Karnataka, Maharashtra, Andhra Pradesh, Tamil Nadu, } \\
\text { Bihar, Rajasthan, Orissa. }\end{array}$ \\
\hline 'less wealth' & $\begin{array}{l}\text { Jharkhand, Chhattisgarh, Madhya Pradesh, Gujarat, } \\
\text { Karnataka, Maharashtra, Andhra Pradesh, Uttaranchal, } \\
\text { Uttar Pradesh, Tamil Nadu, Bihar, Assam, West Bengal. }\end{array}$ \\
\hline 'living in rural areas' & $\begin{array}{l}\text { Jharkhand, Chhattisgarh, Madhya Pradesh, Gujarat, } \\
\text { Karnataka, Maharashtra, Andhra Pradesh, Uttaranchal, } \\
\text { Uttar Pradesh, Tamil Nadu, Bihar, Rajasthan, Himachal } \\
\text { Pradesh, Assam, Haryana. }\end{array}$ \\
\hline 'financial instability within her family' & $\begin{array}{l}\text { Jharkhand, Chhattisgarh, Madhya Pradesh, Gujarat, } \\
\text { Karnataka, Maharashtra, Andhra Pradesh, Uttaranchal, } \\
\text { Uttar Pradesh, Rajasthan, Himachal Pradesh, Orissa, } \\
\text { Tripura. }\end{array}$ \\
\hline
\end{tabular}

Now, there are lots of unquantifiable factors like geographical position of the area, climate and work-culture of the area, historical background of the area, socio-cultural and political condition of the area which play very significant role in the above mentioned variations among the states of India. 
One can classify the states into five categories according to the presence of the four 'push factors'. The first category has all the four 'push factors' present in them. The second category is having three of the four factors. Two of the 'push factors' are present in the states of third category. The states of fourth category are showing only one 'push factor' within themselves, and the labourforce participation decision of the women of the states in the fifth category is not influenced by any of the 'push factors'.

It can be suggested that for the first category, where all four 'push factors' are present, adjusted PCI component in GDI and GEM should be reduced most and so on. Adjusted PCI should not be changed at all when the "push factors' are absent.

Recommendations-

It can be recommended from the above discussions that, the adjusted PCI component of GDI and GEM may be multiplied by $1 / 5$ for first category of states; $2 / 5$ for second category, $3 / 5$ for third category, $4 / 5$ or fourth category and 5/5 (i.e. unchanged) in case of the three states of last category.

There can be changes in ranks of Indian states as per GDI and GEM before and after that modification. In the states where 'push factors' are absent, their ranks in GDI and GEM may increase. Similarly, the states having all four 'push factors' may lose their ranks.

The above recommendations have been exercised on the GDI, GEM figures of Indian states calculated by UNDP in 2006. After the modification, a rank of some states has been changed according to GDI and/or GEM.

The table 4 shows the changes in ranks of Indian states as per GDI and GEM before and after that modification. In the states where push factors are absent, their ranks in GDI and GEM increase. Similarly, the states having all four push factors lose their ranks.

Table 4. Changes in GDI and GEM rankings

\begin{tabular}{|c|c|c|c|c|c|c|}
\hline \multicolumn{3}{|l|}{ GDI } & \multicolumn{4}{|c|}{ GEM } \\
\hline State & \multicolumn{2}{|c|}{ post } & state & pre & post & \\
\hline Kerala & 1 & 1 & Andhra Pradesh & & 1 & 6 \\
\hline Maharashtra & 2 & 11 & Haryana & & 2 & 3 \\
\hline Himachal Pradesh & 3 & 7 & Kerala & & 3 & 1 \\
\hline & 4 & 2 & Maharashtra & & 4 & 8 \\
\hline Punjab & 4 & 2 & Tamil Nadu & & 5 & 5 \\
\hline Tamil Nadu & 5 & 9 & Karnataka & & 6 & 11 \\
\hline Uttarakhand & 6 & 10 & Punjab & & 7 & 2 \\
\hline Haryana & 7 & 3 & Himachal Pradesh & & 8 & 4 \\
\hline Gujarat & 8 & 14 & Gujarat & & 9 & 10 \\
\hline Tripura & 9 & 4 & Madhya Pradesh & & 10 & 9 \\
\hline West Bengal & 10 & 6 & Uttar Pradesh & & 11 & 12 \\
\hline & & & West Bengal & & 12 & 7 \\
\hline Karnataka & 11 & 15 & Chhattisgarh & & 13 & 19 \\
\hline Assam & 12 & 8 & Uttarakhand & & 14 & 15 \\
\hline Andhra Pradesh & 13 & 17 & Rajasthan & & 15 & 16 \\
\hline Jammu \& Kashmir & 14 & 5 & Assam & & 16 & 13 \\
\hline Jharkhand & 15 & 19 & Bihar & & 17 & 18 \\
\hline Chhattisgarh & 16 & 20 & Orissa & & 18 & 14 \\
\hline Orissa & 17 & 12 & Tripura & & 19 & 17 \\
\hline Oinsa & 18 & 12 & Jharkhand & & 20 & 21 \\
\hline Rajasthan & 18 & 13 & Jammu \& Kashmir & & 21 & 20 \\
\hline Madhya Pradesh & 19 & 21 & & & & \\
\hline Uttar Pradesh & 20 & 16 & & & & \\
\hline Bihar & 21 & 18 & & & & \\
\hline
\end{tabular}

Source-'Gendering Human Development Indices: Recasting the Gender Development Index and the Gender Empowerment Measure for India’ Report, 2009

The TABLE 4 shows the changes of ranks among the Indian states according to GDI and GEM. According to GDI, the ranks of Maharashtra and Gujarat reduced from 2 to 11 and 8 to 14 respectively after the modifications. On the other hand, the ranks of Jammu \& Kashmir and West Bengal increased from 14 to 5 and 10 to 6 respectively. Similarly, in case of GEM, Andhra Pradesh and Karnataka lost their ranks from 1 to 6 and 6 to 11 respectively. Again, Kerala and Punjab have gained their ranks from 3 to 1 and 7 to 2 respectively. These are some major changes. The ranks of almost all other states of India have also been changed with the alteration in calculation. Therefore, this modification can change the total scenario in the context of GDI and GEM calculation. 
Policy implications-

Only the figures related to female labourforce participation rate may not tell the situation of female. If this rate is more due to the prevalence of 'negative, push factors', it may reveal poor conditions of women of that area. Whereas, if it is due to 'positive, pull factors', it can show a better condition of women.

Before drawing any conclusion on the situation of women of an area, one has to go through the different socialeconomical-personal-cultural determinants.

The above analysis indicates the variety of rankings of GDI as well as GEM can be obtained for Indian states by incorporating the impact of some social and personal factors. The sharp changes in ranks show the need for exercising some modifications while using these indicators for deriving policy recommendations.

\section{References-}

[1]. Boris Branisa, Stephan Klasen; "New Measures of Gender Inequality: The Social Institutions and Gender Index (SIGI) and its Subindices"; Paper provided by Courant Research Centre PEG in its series Courant Research Centre: Poverty, Equity and Growth Discussion Papers with number 10.

[2]. Foley C. and G. York Adam (2005); "The Effect of Children on Female Labor Supply in the United States from 1950 to 2000"; Presented at the 2005 Western Economic Association International meetings.

[3]. Fred C. Pampel, Kazuko Tanaka, University of Iowa (2004), "Economic Development and Female Labor Force Participation: A Reconsideration", Discussion Paper No. 2004/05, The World Institute for Development Economics Research (WIDER)

[4]. Gauthier Lanot and Christophe Muller (1997); "Dualistic sector choice and female labour supply: evidence from formal and informal sectors in Cameroon"; The Centre for the Study of African Economies Working Paper Series. Working Paper 57.

[5]. Greenstein, Theodore N., "Marital disruption and the employment of married women", Journal of Marriage and the Family, 52:657$676,1990$.

[6]. Harriss Barbara White (2005), "Commercialization, Commodification and Gender Relations in Post-Harvest Systems for Rice in South Asia”, Economic and Political Weekly, June 18, 2005.

[7]. Hotchkiss Julie L. (2005), "What's Up with the Decline in Female Labor Force Participation?" Working Paper 2005-18.

[8]. Jacques Charmes, Saskia Wieringa(2003), "Measuring Women's Empowerment: an assessment of the Gender-related Development Index and the Gender Empowerment Measure", Journal of Human Development and Capabilities, Volume 4, Issue 3 November 2003 , pages $419-435$

[9]. Jean-Christophe Dumont, John P. Martin, Gilles Spielvoge (2007), "Women on the Move: The Neglected Gender Dimension of the Brain Drain", OECD Discussion Paper No. 2920, July 2007

[10]. K. Seeta Prabhu, P. C. Sarker, A. Radha(1996), "Gender-Related Development Index for Indian States: Methodological Issues", Economic and Political Weekly, Vol. 31, No. 43 (Oct. 26, 1996).

[11]. Kodoth, P. and Eapen Mridul (2005), "Looking Beyond Gender Parity: Gender Inequities of Some Dimensions of Well Being in Kerala", Economic and Political Weekly, July 23, 2005.

[12]. Mapalad-Ruane M.C.M.; Rodriguez C.B.(2003), "Measuring Urban Well-Being: Race and Gender Matter", The American Journal of Economics and Sociology, Volume 62, Number 2, April 2003 , pp. 461-483(23)

[13]. Mitra Sona (2006), "Patterns of Female Employment in Urban India: Analysis of NSS Data (1983 to 1999-2000)", Economic and Political Weekly, 41(48).

[14]. Moshe Semyonov(1980), "The Social Context of Women's Labor Force Participation: A Comparative Analysis", The American Journal of Sociology, Vol. 86, No. 3, (Nov., 1980), pp. 534-550

[15]. Nancy Folbre; Measuring Care: Gender, Empowerment, and the Care Economy(2006), "Journal of Human Development and Capabilities", Volume 7, Issue 2 July 2006 , pages 183 - 199

[16]. Purnamita Dasgupta and Bishwanath Goldar (2005), "Female Labour Supply in Rural India: An Econometric Analysis", Institute of Economic Growth, Delhi University Enclave, November 2005

[17]. Roger Clark, Thomas W. Ramsbey, Emily Stier Adler(1990), "Culture, Gender, and Labor Force Participation: A Cross-National Study", Gender and Society, Vol. 5, No. 1, (Mar., 1991), pp. 47-66

[18]. Saget C. (1999), "The determinants of female labour supply in Hungary”, Economics of Transition, Vol. 7(3), pp 575-591.

[19]. Shobna Sonpar and Ravi Kapur (2001), "Non-Conventional Indicators: Gender Disparities under Structural Reforms", Economic and Political Weekly, Vol. 36, No. 1 (Jan. 6-12, 2001), pp. 66-78 